Dept. of Pathology of Reproduction,

Animal Reproduction Research Institute,

Al Haram, Giza, Egypt (P. O. B. 12556), Giza, Egypt.

\title{
PATHOLOGICAL EFFECT OF ACRYLAMIDE ON THE REPRODUCTIVE PERFORMANCE OF THE MALE RABBIT
}

(With 5 Tables and 5 Figures)

\section{By}

\section{M.M. ASSI and M.R. BADR*}

* Dept. of Artificial Insemination and Embryo Transfer, Animal Reproduction Research Institute, Al Haram, Giza, Egypt (P.O.B. 12556), Giza, Egypt.

(Received at 9/6/2011)

دراسات باتولوجية على تأثير الأكريلاميد على الجهاز التناسلى الأكرى الأي

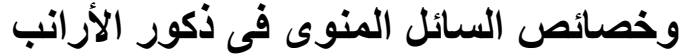

\section{محمد محمد أحمد عاصسى، مجلى رمضان بلر}

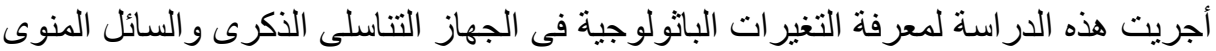

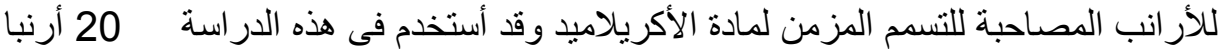

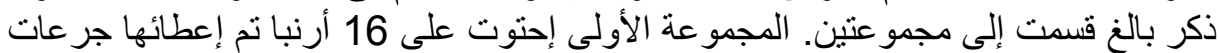
يومية من مادة الأكريلاميد بمعدل 63 مجم / كجم من وزن الجسم لمدة 56 يوم وقد وقد أعطيت هذه الجرعات عن طريث الفم. أما المجموعة الثانية التى تتكون من من

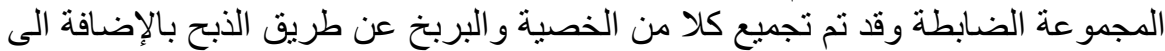

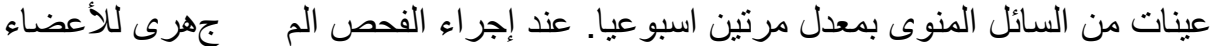
التناسلية لوحظ وجود تغير ات باثولوجية متمثلة فى إحتقان و إرتنشاحات بين القنيات التئ المنوية وبفحص البربخ لوحظ وجود أرنشاحات مائية و هذه التغيرات كانت منشابهة في نو فيتها فئها

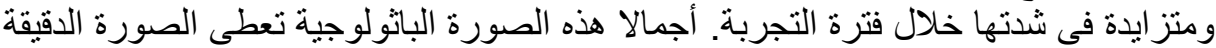

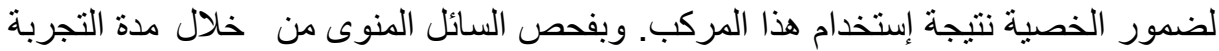
لوحظ وجود إنخفاض فى حركة المنى فى القذفة و عدد الحيو انات المنوية. بينما لوحظ زيادة

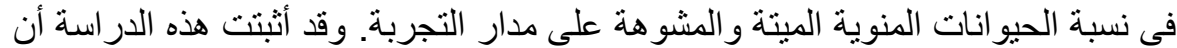

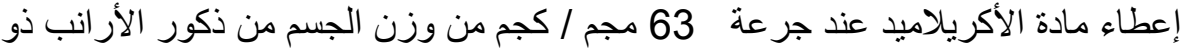

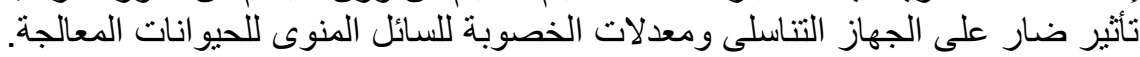

\section{SUMMARY}


Acrylamide caused significant increases in sperm head abnormalities, decreased entry of sperm to uterus and consequently decreased in the fertility rate. Therefore, present study aimed at evaluating the histopathologic adverse effects of toxicity of acrylamide on the male genital organs with special reference to semen quality. Male rabbit (buck) were classified into 2 groups. Group I consisted of sixteen rabbits which were daily intubated orally with acrylamide soluble in water, given with stomach tube until the end of the experiment. Group II consisted of 4 animals and they were kept as a control. The daily dose was $63 \mathrm{mg}$ acrylamide/Kg body weight up to 8 weeks-the whole length of spermatogenic cycle in rabbit. Four rabbits were sacrificed each two weeks, from intoxicated group, while 2 rabbits were sacrificed on the 2nd week and at 8th weeks from the control group. Semen was collected twice weekly using a teaser and an artificial vagina. The semen samples were assessed immediately after collection for, individual motility, sperm abnormality, sperm cell concentration and acrosomal integrity. The present results revealed that, acrylamide treatment resulted in severe testicular lesions giving the picture of testicular atrophy; the seminiferous tubules showed severe and over spread interstitial edema and prominent testicular degeneration. Acrylamide treatment resulted in a significant reduction in the sperm individual motility, total sperm abnormalities and the sperm cell concentration. Meanwhile, the percentage of the dead sperm and the total sperm abnormalities were significantly increased. Finally, it could be concluded that oral daily administration of $63 \mathrm{mg} / \mathrm{kg} \mathrm{B}$.W acrylamide to the male rabbit up to 8 weeks has a generalized deleterious effect, particularly on fertility parameters as evidenced from semen evaluation and the associated testicular degeneration.

Key words: Pathology, acrylamide, reproductive performance, rabbits.

\section{INTRODUCTION}

Acrylamide is water soluble, vinyl monomer used mainly in chemical industries and in the molecular laboratories for the production of polyAcrylamide gel electrophoresis beside the use of polyAcrylamide in water purification, cosmetics and as a soil stabilizer (Gold and Schaumberg, 2000). Acrylamide is used as a binding, thickening or flocculating agent in water treatment, pesticide formulations, cosmetics, sugar manufacturing and soil erosion prevention. The polymers of the compound are used in food packaging and in plastic products (European 
Union, 2002) Moreover, acrylamide might be formed in some food substances cooked at high temperature and the highest concentration of acrylamide had been identified in potato chips and French fries as high as $3500 \mathrm{mg} / \mathrm{kg}$ and grain based food that were cooked at high temperature Tareke et al. (2002). In addition, acrylamide was formed during the reaction between amines and carbonyl compounds especially reducing sugars and this reaction occurred in heated, dried or stored foods but also in vivo in mammalian organism. They added that about $50 \%$ of the overall acrylamide intake was from food cooked Stadler and Gabriele (2004). The main route of exposure to acrylamide can occur through air, water, land and ground water (ACGIH, 2005). Regardless the route of exposure, acrylamide appeared to have high affinity to distribute rapidly throughout tissue Sumner et al. (2001). The main route of acrylamide absorption was injured skin, mucous membrane, lung and the gastrointestinal tract Merck (1998). Acrylamide was not eliminated from water after treatment processes because of the monomeric acrylamide is very soluble in water and is not readily absorbed by sediments FAO/WHO (2002). Environmental exposure to acrylamide resulted in neurotoxicity (Gold and Schaumberg, 2000). The conversion of acrylamide to glycamide considered as an important step in the mechanism of neurotoxicity (Abou-Donia et al., 1993), acrylamide also, exerts a destructive and a significant carcinogenic effect on the reproductive and nervous system of the laboratory animals that involving modifications of kinesin and sulfhydryl groups of other proteins by acrylamide and/or glycamide and a separate mechanism for male dominant lethal mutations involving clastogenic effects from acrylamide and/or glycamide interactions with protamine or spindle fiber proteins in spermatids and/or direct alkylation of DNA by glycamide. (Tyl et al., 2000; Lopachin et al., 2003; Perrault, 2003).

Moreover, acrylamide toxicity extended to produce hepatotoxicity and genotoxicity (Cihak and Vontorkova, 1998). Moreover, acrylamide macroscopically caused testicular atrophy and reduction in testicular weight NTPTR (1989), and microscopic degeneration of the seminiferous tubules' lining epithelia especially those of spermatids and spermatocytes, scrotal tumor, reduction in the number of spermatozoa, degeneration of spermatids and spermatozoa and formation of multinucleated giant cells (Costa et al., 1992; Hye et al., 2004; Lee et al., 2005). Furthermore, the administration of acrylamide caused significant increases in sperm head abnormalities, decreased both sperm motility and entry of sperm to uterus and 
consequently decreased in the fertility rate (Sublet et al., 1989; Tyl et al., 2000; Hye et al., 2004). Therefore, present study aimed at evaluating the histopathologic adverse effects of toxicity of acrylamide on the male genital organs with special reference to semen quality.

\section{MATERIALS and METHODS}

\section{Material:}

Animals: The present study was carried out on 20 mature male New Zealand rabbits (7 month old, weighed about $1700 \mathrm{~g}$ ) purchased from farms of the ministry of agriculture. They were given water adlibitum. All rabbits were housed in metal cages and received a balanced ration diet for two weeks before the start of the experiment. Acrylamide ( $\mathrm{CH} 2 \mathrm{CHCONH} 2)$, it was obtained from Sigma Co. (A. 494537).

\section{Methods:}

\section{Experimental design:}

Animals were classified into 2 groups. Group I consisted of sixteen rabbits which were daily intubated orally with acrylamide soluble in water, given with stomach tube until the end of the experiment. Group II consisted of 4 animals and they were kept as a control. The daily dose was $63 \mathrm{mg}$ acrylamide/Kg body weight according to McCollister et al. (1964), up to 8 weeks-the whole length of spermatogenic cycle in rabbit (Steger., 2005). Four rabbits were sacrificed each two weeks, from intoxicated group, while 2 rabbits were sacrificed on the 2nd week and at 8th weeks from the control group.

\section{Semen collection and evaluation:}

Semen was collected twice weekly using a teaser and an artificial vagina. The semen samples were assessed immediately after collection for, individual motility, sperm abnormality, sperm cell concentration and acrosomal integrity according to Woston and Martin (1972).

\section{Pathological examination:}

The necropsy protocol was designed to study the alteration associated with acrylamide toxicity. Gross lesions at the time of necropsy were recorded. Specimens of the testes were collected and fixed in $10 \%$ buffered neutral formalin. Then, the samples were dehydrated in ascending grades of alcohol and embedded in paraffin wax, mounted, sectioned at $5 \mu \mathrm{m}$ and stained with hematoxylin and eosin (H\&E) and then examined by the light microscope. (H\&E; Bancroft and Stevens, 1996). 


\section{Statistical analysis:}

Data of semen analysis were statistically analyzed for the effects of intoxication using the GLM procedure of the SAS computer program (SAS, 1987).

\section{RESULTS}

\section{Histopathological examination of the testes:}

The most pronounced effect of acrylamide poisoning was noticed in the testes as shown in (Figs.1, 2 and 3). Mild testicular changes were noticed during the 2 nd week consisting of slight to moderate edema of the interstitial tissue, the edematous fluid appeared homogenous and faintly eosinophilic. Moreover, some seminiferous tubules showed vacuolar degeneration of the lining spermatogenic cells. In addition, mild tubular degeneration with degenerated spermatids and residual bodies in the lumen of the seminiferous tubules was prominent. Meanwhile on the 4th week, the detectable lesions were nearly similar to those previously mentioned during the 2 nd week but were increased in severity and extension. The testicular lesions were marked interstitial edema, and much more vacuolated germinal epithelial cells. The tubular degeneration became somewhat moderate with increased number of the degenerated spermatids and residual bodies in the lumen of the seminiferous tubules. The recorded lesions during the 6th week also had the same characters as in 4th week and became more severe and diffuse. The testicular lesions were severe interstitial edema. The tubular degeneration became marked and advanced with increased number of the degenerated spermatids and residual bodies in the lumen of the seminiferous tubules and decreased number of the germinal epithelial rows, Some of the seminiferous tubules showed various numbers of testicular giant cells and presence of residual bodies. During the $8^{\text {th }}$ week of treatment, the testicular lesions turned to be severe giving the picture of testicular atrophy, the seminiferous tubules showed severe and over spread interstitial edema and drastic and prominent testicular degeneration which in some cases exhibited complete absence of the germinal epithelial cells with the presence of only one layer of spermatogenic and Sertoli cells and in others presence of one or few layers of the germinal cell.

Moreover, the encountered epididymal lesions were in the form of vacoular degeneration of the ductal epithelium and interstitial 
oedema. The severities of the detectable lesions were increased in time dependant manner.

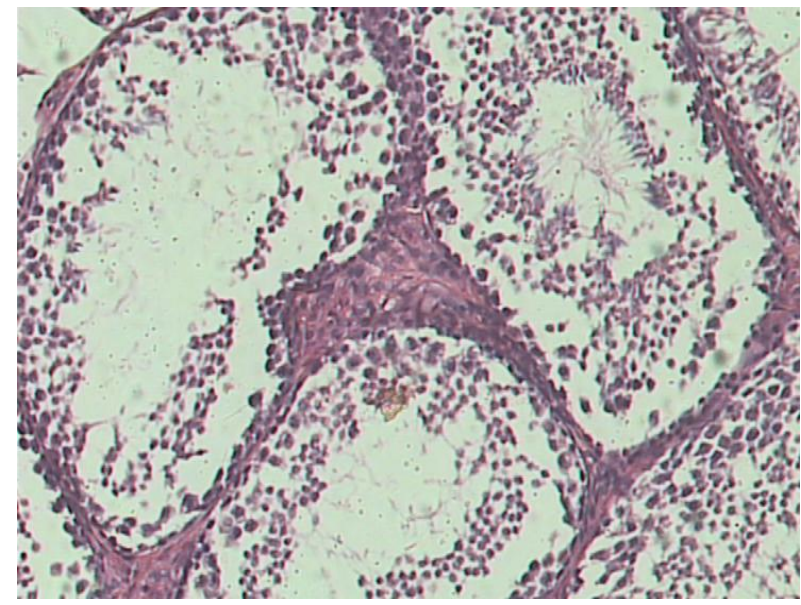

Fig. 1: Testis of a rabbit 4 weeks postintoxication with acrylamide showed sever tubular degeneration and degenerated spermatides in the tubular lumen. Interstitial oedema was noticed. (X10)

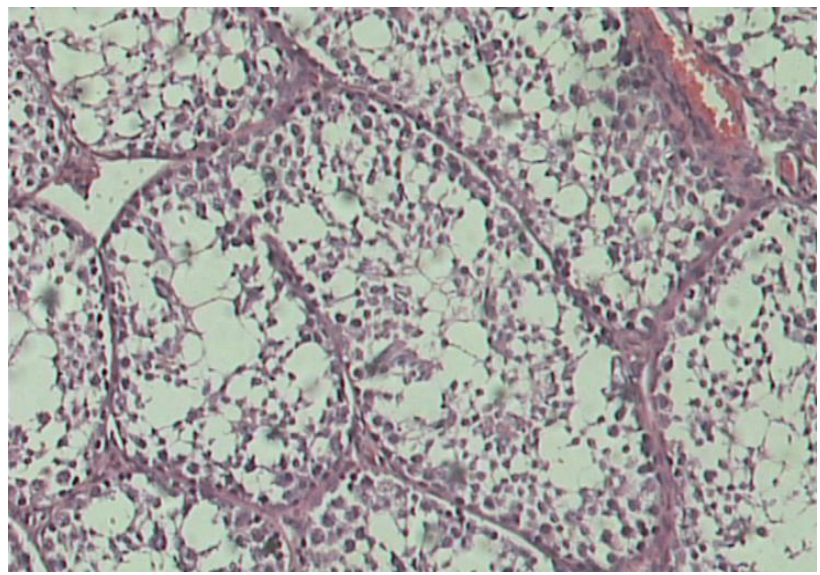

Fig. 2: Testis of a rabbit 8 weeks postintoxication with acrylamide showed advanced tubular degeneration and increased number of degenerated spermatides in the tubular lumen. Dilated and congested blood vessels was seen. (X10) 


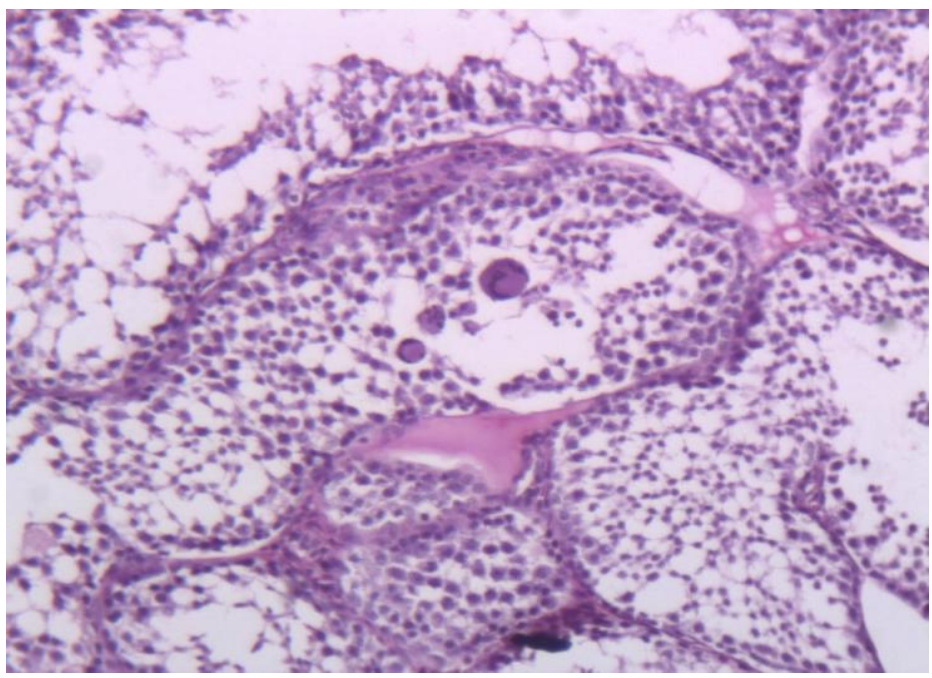

Fig. 3: Testis of a rabbit 8 weeks postintoxication with acrylamide showed severe tubular degeneration and gaint cell formation in the tubular lumen (X10).

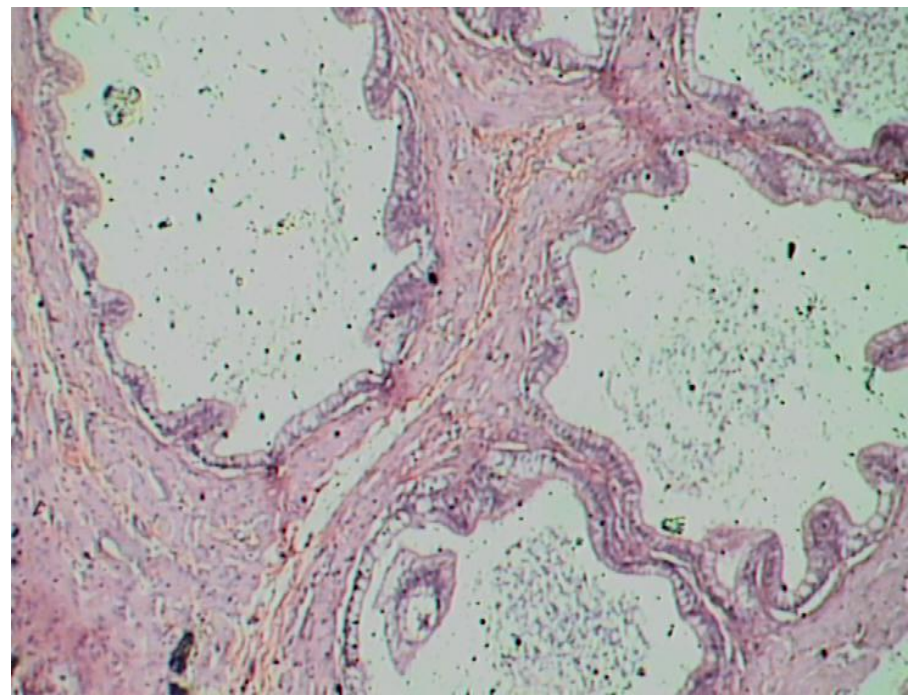

Fig. 4: Epididymis of a rabbit 8 weeks postintoxication with acrylamide showed severe vaccular degeneration lining epithelium and interstitial oedema (X 10)

Effect of acrylamide on semen quality of the buck: 
Acrylamide treatment resulted in drastic effects on semen quality as shown in Fig. 5 (A, B, C and D). Data present in table 1 revealed that, there was a significant reduction of sperm individual motility throughout the whole experiment when compared with the control group.

Table 1: Effect of acrylamide on sperm motility (\%) of buck (mean \pm $\mathrm{SE})$.

\begin{tabular}{|l|c|c|c|c|}
\hline \multirow{2}{*}{ Group } & \multicolumn{4}{|c|}{ Experimental Period (weeks) } \\
\cline { 2 - 5 } & 2 & 4 & 6 & 8 \\
\hline Acrylamide & $50.42 \pm 1.89^{\mathrm{a}} *$ & $45.83 \pm 1.61^{\mathrm{a} *}$ & $45.83 \pm 2.29^{\mathrm{a} *}$ & $35.42 \pm 1.44^{\mathrm{b} *}$ \\
\hline Control & $77.08 \pm 1.50^{\mathrm{a}}$ & $77.50 \pm 2.50^{\mathrm{a}}$ & $75.00 \pm 2.24 \mathrm{a}$ & $81.67 \pm 1.05^{\mathrm{a}}$ \\
\hline
\end{tabular}

Values with different letters in the same row are significantly different at least $(\mathrm{P}<0.05)$.

* Acrylamide and control means within a week differ significantly $(\mathrm{P}<0.01)$.

Regarding the effect of acrylamide on the sperm concentration, the concentration was significantly decreased from the 2nd week till the end of the experiment, particularly on the 8th week as shown in Table (2).

Table 2: Effect of acrylamide on sperm cell concentration (millions/ ml) of the buck (mean \pm SE).

\begin{tabular}{|l|c|c|c|c|}
\hline \multirow{2}{*}{ Group } & \multicolumn{4}{|c|}{ Experimental Period (weeks) } \\
\cline { 2 - 5 } & 2 & 4 & 6 & 8 \\
\hline Acrylamide & $285.42 \pm 9.12^{\mathrm{a}^{*}}$ & $269.58 \pm 7.29^{\mathrm{ab} *}$ & $243.33 \pm 10.47^{\mathrm{b} *}$ & $145.83 \pm 10.48^{\mathrm{c} *}$ \\
\hline Control & $625.00 \pm 9.25^{\mathrm{b}}$ & $618.33 \pm 7.92^{\mathrm{b}}$ & $641.67 \pm 19.39^{\mathrm{b}}$ & $700.00 \pm 11.25^{\mathrm{a}}$ \\
\hline
\end{tabular}

Values with different letters in the same row are significantly different at least $(\mathrm{P}<0.05)$.

* Acrylamide and control means within a week differ significantly $(\mathrm{P}<0.01)$.

As regards, the dead sperm percentage was significantly increased throughout the experiment, particularly on the 8th week (last week of the experiment) as shown in Table (3). 

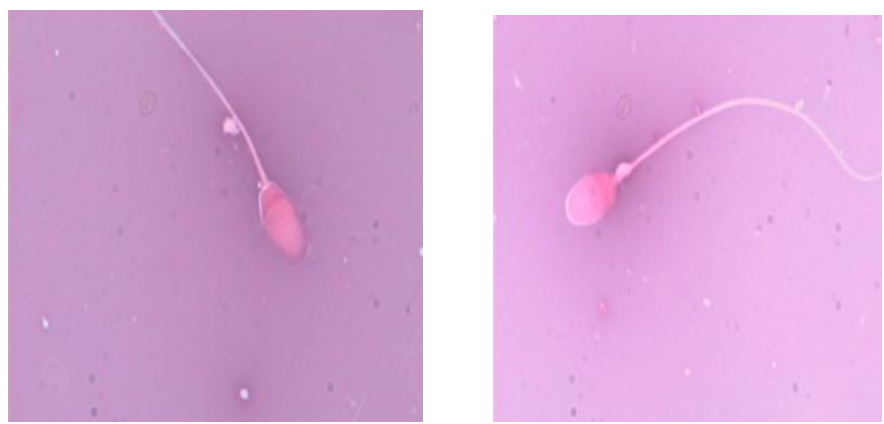

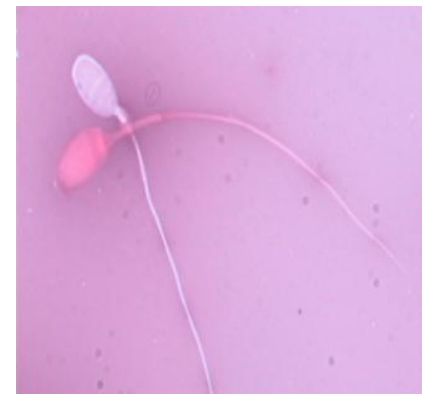

Fig. 5: A- Abnormal head C- Dead (red) sperm

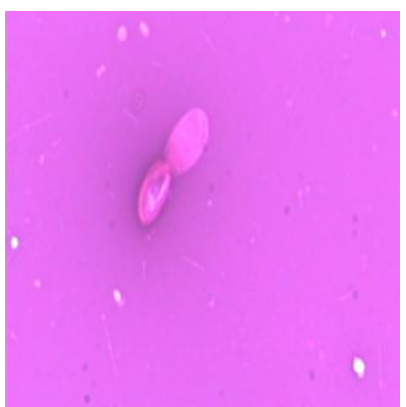

B- Proximal protoplasmic droplet D- Coiled tail

Table 3: Effect of acrylamide on sperm live dead (\%) of the buck (mean $\pm \mathrm{SE}$ ).

\begin{tabular}{|l|c|c|c|c|}
\hline \multirow{2}{*}{ Group } & \multicolumn{4}{|c|}{ Experimental Period (weeks) } \\
\cline { 2 - 5 } & 2 & 4 & 6 & 8 \\
\hline Acrylamide & $60.17 \pm 1.47^{\mathrm{a}^{*}}$ & $56.50 \pm 1.98^{*}$ & $59.17 \pm 1.72^{\mathrm{a}}$ & $50.42 \pm 1.79^{\mathrm{b}}$ \\
\hline Control & $83.75 \pm 0.90^{\mathrm{a}}$ & $85.00 \pm 1.29^{\mathrm{a}}$ & $83.33 \pm 1.67^{\mathrm{a}}$ & $86.67 \pm 1.05^{\mathrm{a}}$ \\
\hline
\end{tabular}

Values with different letters in the same row are significantly different at least $(\mathrm{P}<0.05)$.

* Acrylamide and control means within a week differ significantly $(\mathrm{P}<0.01)$.

Concerning the effect of the acrylamide on the percentage of total sperm abnormalities, the current results demonstrated that, there was a significantly increased in the total sperm abnormalities in comparison with control from the 2 nd week of the experiment and 
onward. The highest abnormal percentage was observed on the 8th week as shown in Table 4. The obtained forms of sperm abnormalities included coiled tail, proximal protoplasmic droplet, and thick mid piece, abnormal head, free head and loose covering sheath of mid piece. The percentage of the acrosomal defects was significantly increased precisely in the same magnitude of changes as previously described in the total sperm abnormalities. Moreover, the forms of the acrosomal defects included knobbed (pointed) acrosome, loose acrosome, detached acrosome and fenestrated acrosome as shown in Table 5.

Table 4: Effect of acrylamide on sperm abnormalities (\%) of the buck (mean $\pm \mathrm{SE})$.

\begin{tabular}{|c|c|c|c|c|}
\hline \multirow{2}{*}{ Group } & \multicolumn{4}{|c|}{ Experimental Period (weeks) } \\
\cline { 2 - 5 } & 2 & 4 & 6 & 8 \\
\hline Acrylamide & $69.00 \pm 3.06^{\mathrm{d} *}$ & $86.83 \pm 1.87^{\mathrm{b} *}$ & $76.83 \pm 2.95^{\mathrm{c}^{*}}$ & $94.25 \pm 1.36^{\mathrm{a}}$ \\
\hline Control & $5.58 \pm 0.26^{\mathrm{a}}$ & $5.17 \pm 0.48^{\mathrm{a}}$ & $5.67 \pm 0.49^{\mathrm{a}}$ & $6.00 \pm 0.58^{\mathrm{a}}$ \\
\hline
\end{tabular}

Values with different letters in the same row are significantly different at least $(\mathrm{P}<0.05)$.

* Acrylamide and control means within a week differ significantly $(\mathrm{P}<0.01)$.

Table 5: Effect of acrylamide on acrosomal abnormalities (\%) of buck $($ mean \pm SE).

\begin{tabular}{|l|c|c|c|c|}
\hline \multirow{2}{*}{ Group } & \multicolumn{4}{|c|}{ Experimental Period (weeks) } \\
\cline { 2 - 5 } & 2 & 4 & 6 & 8 \\
\hline Acrylamide & $12.33 \pm 0.71 \mathrm{c}^{*}$ & $19.75 \pm 0.73 \mathrm{~b}^{*}$ & $18.75 \pm 1.01 \mathrm{~b}^{*}$ & $26.75 \pm 0.70^{*}$ \\
\hline Control & $4.50 \pm 0.15^{\mathrm{a}}$ & $4.33 \pm 0.21^{\mathrm{a}}$ & $4.83 \pm 0.31^{\mathrm{a}}$ & $4.67 \pm 0.21$ \\
\hline
\end{tabular}

Values with different letters in the same row are significantly different at least $(\mathrm{P}<0.05)$.

* Acrylamide and control means within a week differ significantly $(\mathrm{P}<0.01)$.

\section{DISCUSSION}

It was established that, acrylamide caused reproductive, neurotoxic, genotoxic, carcinogenic and immunosuppressive effects in laboratory animals (Matsuoka et al., 1993; Tsuda et al., 1993). In the 
present study, the encountered clinical signs were depression, dullness, in appetence, loss of the body weight, skeletal muscle weakness and development of neuropathic syndrome as (ataxia and dragging of the hind limb). These results were confirmed with many previous literatures (Yousef and EL-Demerdash, 2005). The current results clearly revealed that acrylamide treatment has a drastic effect on the semen quality and sperm cell concentration. These findings were in consistent with the (Hye et al., 2004) who demonstrated that acrylamide treatment caused a significant reduction of the sperm concentration. Moreover, the present data showed that, sperm motility was severely reduced and this result was in agreement with those reported by (Tyl et al., 2000) who confirmed that acrylamide induced a highly significant reduction in the percentage of the mobile spermatozoal cell. In the present study the number of the dead sperm in comparison to live sperm was significantly increased, this result was concurred with the results observed by (U.S.EPA, 1989) who suggested that acrylamide has very injurious effect to spermatogenesis particularly on spermatid and spermatozoa. Furthermore, acrylamide treatment significantly increased the acrosomal and total abnormalities of spermatozoa. These results were comparable with those mentioned by Hye et al. (2004); Kadry (2007) and El-Neweshy (2008) who concluded that acrylamide has a harmful injurious effect on spermatozoa.

In concern to the testis, the present study showed interstitial edema that observed as a sequel of the state of congestion of the interstitial capillaries where these congested vessels became more permeable. Moreover, the testicular lesions were typical of severe focal testicular degeneration (seminiferous epithelial vacoulation and desqumtion with intratubular gaint cell formation). Testicular spermatocytic gaint cells may be formed from fusion of degenerated spermatides (Chapin et al., 1988), however, others suggested that nuclear divisions of the spermatogenic cells without cell separation is considered the cause of giant cell formation (Mitranond et al., 1979). Absence of mitotic figures inside the giant cell in this study supported the cellular fusion as the cause of spermatocytic giant cell formation. These results were in accordance with those of (Hye et al., 2004; Lee et al., 2005).

Finally, it could be concluded that oral daily administration of acrylamide at the level of $63 \mathrm{mg} / \mathrm{kg} \mathrm{B.W}$. to male rabbit up to 8 weeks has a generalized deleterious effect, particularly on fertility parameters as evidenced from semen evaluation and the associated testicular 
degeneration. Moreover, additional researches are needed to determine whether these adverse effects are reversible or not.

\section{REFERENCES}

Abou Donia, I.M.; Corcoran, J.; Lack, L.; Friedman, A. and Lapadula, M. (1993): Neurotoxicity of glycidamide and acrylamide metabolite following intraperitoneal injection in rats. J. Toxicol. Environ. Health; 39: 447-464.

ACGIH "American Conference of Governmental Industrial Hygienists" (2005): Acrylamide. In: Documentation of threshold limit values and biological exposure indices. 7th Ed., Vol. 1. Cincinnati, $\mathrm{OH}$ : American Conference of Governmental Industrial Hygienists.

Bancroft, J.D. and Stevens, A. (1996): Theory and Practice of Histological echniques. Fourth edition.

Chapin, R.; Dalton, S.; Ross, M.; Sumrell, B. and Lamb, J. (1988):

Development of reproductive lesions in male F-344 rats after treatment with dimethyl phosphate. Expt. mol. Pathol; 41: 126-140.

Cihak, $R$. and Vontorkova, M. (1998): Cytogenic effect of acrylamide in the bone marrow of mice. Mutat. Res.; 209(1-2): 91-94.

Costa, L.G.; Deng, H.; Gregotti, C.; Manzo, L.; Faustman, E.M.; Bergmark, E. and Calleman, C.J. (1992): Comparative studies on the neuro- and reproductive toxicity of acrylamide and its epoxide metabolite glycidamide in the rat. Neurotoxicology; 13: 219-224.

El-Neweshy, M.S. (2008): Pathological studies on acrylamide toxicosis in Nile Tilapia. Ph.D. Thesis, Fac. vet. Med., Alex Univ.

European Union (2002): European Commission, European Chemicals

Bureau, Institute for Health and Consumer Protection, European Union Risk Assessment Report Acrylamide. Office for Official Publications of the European Communities. uxembourg.

FAO/WHO (2002): Consultation on the health implication of acrylamide in food. Geneva: 25-27.

Gold, B.G. and Schaumberg, H.H. (2000): Acrylamide in: Spencer, P.S. Schaumburg, H.H. Ludolph, A.C. editors, Experimental and Clinical Neurotoxicity. $2^{\text {nd }}$ edition, New York, Oxford University Press., 124: 132-140.

Hye, J.; Sang, H.; Yong, J.; Jin, H.; Dong, U.; Chan, C.; Mun, H. and Chang, M. (2004): Toxicological effects of acrylamide on rat 
testicular gene expression profile. Reproductive Toxicology; 19: 527-534.

Kadry, M.I. (2007): Biochemical effects of acrylamide on some tissues and serum constituents in rabbits. M.V.Sc. Thesis, Fac. vet. Med., Alex. Univ.

Lee, K.Y.; Shibutani, M.; Kuroiwa, K.; Takagi, H.; Inoue, K.; Nishikawa, H.; Miki, T. and Hirose, M. (2005): Chemoprevention of acrylamide toxicity by antioxidative agents in rats, effective suppression of testicular toxicity by phenylethyl isothiocyanate. Arch. Toxicol.; 79: 531-541.

LoPachin, R.M.; Balaban, C.D. and Ross, J.F. (2003): Acrylamide axonopathy revisited. Toxicol. Appl. Pharmacol.; 188: 135-153.

Matsouka, M.; Inoric, N.; Igisu, H. and Kohriyama, K. (1993): Effect of neurotoxins on brain creatine kinase activity. Environ. Res.; 6 (11): 37-42.

McCollister, D.; Oyen, F. and Rowe, V. (1964): Toxicology of acrylamide. Toxicol. Appl. Pharmacol.; 6: 172-181.

Merck (1998): Mortha Wendhaliz, ed. Rahway NJ USA, merck index 10th Edition and co.Inc.; 112-119.

Mitranond, V.; Soblon, P.; Tosukaowong, P. and Gthedabangrat, W. (1979): Cytological changes in testis of vitamin A deficiency rats. Acta anato.; 103: 159-168.

NTPTR (1989): National Toxicology Program Technical Report Series. Research Triangle Park, (NC 27709) No. 206.

Perrault, S.D. (2003): Distinguishing between fertilization failure and early pregnancy loss when identifying male-mediated adverse pregnancy outcomes. Adv. Exp. Med. Biol.; 518: 189-198.

Stadler, R.H. and Gabriele, S. (2004): Acrylamide: Levels in Food, Mechanism of Formation, and Potential Strategies. Nutrition Reviews. International Life Sciences Institute; 62(12): 449-467.

Steger, K. (2005): Effect of vasoectomy on sperm nuclear chromatin in rabbit. J. Andrology; 39(4): 124-127.

Sublet, V.H.; Zenick, H. and Smith, M.K. (1989): Factors associated with reduced fertility and implantation rates in females mated to acrylamide-treated rats. Toxicology; 55: 53-67.

Sumner, S.C.; Fennell, T.R.; Snyder, R.W. and Krol, W.L. (2001): Comparison of the hemoglobin adducts formed by administration of N-methylolacrylamide and acrylamide to rats. Toxicological Sciences; 71: 164-175. 
Tareke, E.; Rydberg, P.; Karlsson, P.; Eriksson, S. and Tongvist, M. (2002): Analysis of acrylamide, carcinogen formed in heated food stuff. J. Agric. Food Chem.; 50: 4998-5006.

Tsuda, H.; Shimizu, C.S.; Taketomi, M.K.; Hasegawa, M. and Hamada, A.; Kawata, K.M. and Inut, N. (1993): Acrylamide; induction of DNA damage, chromosomal aberration and cell transformation without gene mutations. Mutagenesis, 8: 23-29.

Tyl, R.W.; Friedman, M.A.; Losco, P.E. and Ross, W.P. (2000): Rat twogeneration reproduction and dominant lethal study of acrylamide in drinking water.Reprod. Toxicol., 14: 385-401.

U.S.EPA. (1989): Health and environmental effects profile for acrylamide. U.S. Environmental Protection Agency., Washington, D.C.: 95.

Woston, S. and Martin, R. (1972): A comparison of change in acrosomes of deep frozen ram and bull spermatozoa. J. Reprod. Fert.; 28: 99-101.

Youssef, M.I. and EL-Demerdash, F.M. (2005): Acrylamide induced oxidative stress and biochemical perturbations in rats. Toxicology; 219: 133-141. 